\title{
Adverse effects in wild fish living downstream from pharmaceutical manufacture
}

discharges

Wilfried Sanchez ${ }^{1 *}$, William Sremski ${ }^{2}$, Benjamin Piccini ${ }^{1}$, Olivier Palluel ${ }^{1}$, Emmanuelle Maillot-Maréchal $^{1}$, Stéphane Betoulle ${ }^{3}$, Ali Jaffal ${ }^{3}$, Sélim Aït-Aïssa ${ }^{1}$, François Brion ${ }^{1}$, Eric Thybaud ${ }^{4}$, Nathalie Hinfray ${ }^{1}$, Jean-Marc Porcher ${ }^{1}$

1. Institut National de l'Environnement Industriel et des Risques (INERIS), Unité d'Ecotoxicologie in vitro et in vivo, BP2, 60550 Verneuil-en-Halatte, France

2. Office National de l'Eau et des Milieux Aquatiques (ONEMA), Délégation InterRégionale Auvergne-Limousin, 63370 Lempdes, France

3. Université de Reims Champagne-Ardennes, Unité de Recherche Vignes et Vins de Champagne - Stress et Environnement EA 2069, Laboratoire Ecologie-Ecotoxicologie, BP 1039, 51687 Reims Cedex 2, France

4. Institut National de l'Environnement Industriel et des Risques (INERIS), Pôle Dangers et Impacts sur le Vivant, BP2, 60550 Verneuil-en-Halatte, France

* Corresponding author. Tel : +33 (0)3 44618121 ; Fax: +33 (0)3 44556767

E-mail address : Wilfried.Sanchez@ ineris.fr (W. Sanchez) 


\begin{abstract}
A set of biochemical and histological responses was measured in wild gudgeon collected upstream and downstream of urban and pharmaceutical manufacture effluents. These individual end-points were associated to fish assemblage characterisation. Responses of biotransformation enzymes, neurotoxicity and endocrine disruption biomarkers revealed contamination of investigated stream by a mixture of pollutants. Fish from sampled sites downstream of the industrial effluent exhibited also strong signs of endocrine disruption including vitellogenin induction, intersex and male-biased sex-ratio. These individual effects were associated to a decrease of density and a lack of sensitive fish species. This evidence supports the hypothesis that pharmaceutical compounds discharged in stream are involved in recorded endocrine disruption effects and fish population disturbances and threaten disappearance of resident fish species. Overall, this study gives argument for the utilisation of an effect-based monitoring approach to assess impacts of pharmaceutical manufacture discharges on wild fish populations.
\end{abstract}

Key-words : pharmaceutical; endocrine disruption; gudgeon; biomarkers 


\section{Introduction}

Recent evidence shows that aquatic ecosystems are contaminated by human and veterinary pharmaceuticals. Indeed, numerous studies reported the quantification of different active pharmaceutical ingredients (APIs) in a variety of environmental matrices including surface water, ground water, effluents and sediments but also biota (Halling-Sorensen et al., 1998; Togola and Budzinski, 2008; Rabiet et al., 2006). The introduction of APIs in aquatic ecosystems comes from various sources. Among them, effluents of waste water treatment plants (Matamoros et al., 2009; Tamtam et al., 2008; Santos et al., 2009) and hospitals (Brown et al., 2006; Kümmerer, 2001) are considered as major sources of such contamination. During many years, drug manufacturers were considered as negligible contributors due to good manufacturing practice regulations and high economic value of APIs (Kümmerer, 2009). A recent study analyzed pharmaceuticals in the effluent from an Indian wastewater treatment plant serving drug manufacturers and revealed a large occurrence of APIs. From among 59 screened pharmaceuticals, 11 of them were detected at a concentration up to $100 \mu \mathrm{g} / \mathrm{L}$ (Larsson et al., 2007). Other investigations performed around the world on effluents from pharmaceutical factories confirmed this result and provided data on surface water contamination induced by these effluents. Indeed, a large variety of pharmaceutical classes such as antibiotics, anti-inflammatory, opioids, muscle relaxants, were encountered in effluents and also in receiving aquatic ecosystems at concentrations between ng/L and mg/L (Yu-Chen Lin and Tsai, 2009; Phillips et al., 2010; Sim et al., 2011).

In aquatic ecosystems discharged APIs induce adverse effects in living organisms including fish (for review see: Fent et al., 2006; Gagné and Blaise, 2004). APIs can 
interfere with a wide range of physiological functions such as xenobiotic biotransformation (Laville et al., 2004), reactive oxygen species regulation (Pagano et al., 2001), hormone synthesis (Mimeault et al., 2005) or reproduction (Nash et al., 2004). A recent 7-year experiment based on chronic exposure of fathead minnow (Pimephales promelas) to low concentrations of the estrogenic pharmaceutical ethynylestradiol, a component of the contraceptive pill, provided evidence that these chemicals can impact the sustainability of wild fish populations (Kidd et al., 2007). However, to our knowledge, no data is available related to impact of pharmaceutical manufacture discharges on downstream aquatic ecosystems.

The present study of individual and populational effects in gudgeons living in this aquatic ecosystem subjected to a pharmaceutical factory discharge began as a consequence of angler's observations reporting morphological fish abnormalities such as abdominal swelling associated to gonad hypertrophy in wild gudgeons (Gobio gobio; Figure 1) living downstream from an industrial effluent. To assess biochemical effects, biomarkers including VTG as endocrine disruption end-point, biotransformation enzymes (7-ethoxyresorufin-O-deethylase (EROD), cytochrome P450 3A (CYP3A) and glutathione-S-transferase (GST) activities), together with acetylcholinesterase (AChE) and lysozyme activities respectively as neurotoxicity and immunotoxicity biomarkers was measured. In this context, biomarkers can be considered as an appropriate tool to integrate the effects of effluent on fish (Sanchez and Porcher, 2009). Biochemical measurements were completed by histological analysis of gonads. Indeed, histology offers a powerful tool for sex verification, identifying stage of development, documenting presence of intersex and other abnormalities. Moreover, histological analysis of reproductive tissues can provide predictive information related to the fitness 
of organisms and their reproduction potential. Combination between biochemical and histological measurements can provide insights into the effects of effluent on fish health and especially reproductive health (Blazer, 2002). To complete the assessment of individual effects, fish assemblage was characterized to identify potential disturbance of fish populations.

\section{Materials and methods}

\subsection{Sampling sites and fish collection}

This study was performed in the Dore river (Puy de Dôme, France). Investigated area is a transitory part between trout and grayling Huet's zonation (Huet, 1949), subjected to industrial and urban pressures corresponding to a pharmaceutical factory producing mainly steroid compounds but also to urban wastewater treatment plant (WWTP) effluents. Three sampling sites were then selected to assess the effects of industrial effluent (Table 1). The site $\mathrm{A}$ is located downstream from a medium size city and is submitted to an urban pollution due to the WWTP effluent (capacity $=8100$ population equivalent, annual mean flow $=2550 \mathrm{~m}^{3} / \mathrm{j}$ ) of this town. However, this site $\mathrm{A}$ is also located upstream from the industrial effluent and is considered as a control site for this study. The site B where abnormal features were previously observed in wild gudgeons (Figure 1), is located downstream from the industrial effluent but also from the WWTP of the city of Vertolaye (capacity $=1800$ population equivalent, annual mean flow $=$ $300 \mathrm{~m}^{3} / \mathrm{j}$ ) and allows assessment of the effect of these effluents in fish. The site $\mathrm{C}$ is located downstream from the site B and allows evaluation of the persistence of effluent effects in fish. In the three sites previously described, gudgeons were electrofished during October 2008 and August 2009. To complete this work with basal level of 
biomarker such as EROD, CYP3A, GST and AChE, in gudgeon, wild fish were caught in August 2009 in a reference site located in the upper area of the Dore river basin and characterized by a lack of environmental pressure.

\subsection{Fish collection and tissue sampling}

After capture, external examination of fish was quickly performed and the occurrence of lesion, parasites and other external features was noted. The fish were weighed, measured to calculate the Fulton's condition factor $\left(\mathrm{CF}=\right.$ fish weight $/$ fish length ${ }^{3}$; Heincke, 1908) and immediately sacrificed by a blow over the head. Blood was removed directly from the caudal vein by means of a heparinised syringe. The blood was centrifuged at $3000 \mathrm{~g}, 4^{\circ} \mathrm{C}$ for $10 \mathrm{~min}$. The plasma was stored at $-80^{\circ} \mathrm{C}$ until VTG analysis. Liver, head kidney and muscle were rapidly dissected, weighed and frozen in liquid nitrogen prior to homogenisation and biochemical analysis. Gonads were removed, weighted for gonad somatic index calculation (GSI= gonad weight/fish weight)x100) and fixed in Bouin's solution and stored in ethanol for histological analysis and gender determination.

\subsection{Biochemical analysis}

Circulating VTG concentration in males was measured using a competitive ELISA. Briefly, Gudgeon-VTG purified according the method developed by Brion et al. (2000) was coated in Nunc Maxisorp microtiter plates (Nunc Roskilde, Denmark) at $50 \mathrm{ng} / \mathrm{mL}$ in $0.05 \mathrm{M}$ carbonate-bicarbonate ( $\mathrm{pH}$ 9.6). Standards and plasma samples were preincubated with the primary antibody raised against Chub-VTG (Covalab, Lyon, France) at a final dilution of 1:5,000. Standard of Gudgeon-VTG was serially diluted with a factor two ranging from 0 to $3,000 \mathrm{ng} / \mathrm{mL}$, and plasma samples were serially diluted five times with a factor of three with an initial dilution of 1:10. Pre-coated 
ELISA microplates were incubated with preincubated primary antibody solution with standards or samples and then with secondary antibody (horseraddish peroxidase goat anti-rabbit IgG diluted 1:2,000 in PBS, $1 \%$ BSA). The peroxidase activity was revealed at $450 \mathrm{~nm}$ by adding $100 \mu \mathrm{l}$ of tetramethylbenzidine enzyme substrate (Kirkegaard and Perry Laboratories, Gaithersburg, MD, USA) and stopping by addition of $50 \mu \mathrm{l}$ of $1 \mathrm{M}$ phosphoric acid $\left(\mathrm{H}_{3} \mathrm{PO}_{4}\right)$.

Livers were homogenised in ice-cold phosphate buffer (100 mM, pH 7.8) with $20 \%$ glycerol and $0.2 \mathrm{mM}$ phenylmethylsulfonyl fluoride as a serine protease inhibitor. The homogenates were centrifuged at $10,000 \mathrm{~g}, 4^{\circ} \mathrm{C}$, for $15 \mathrm{~min}$ and the postmitochondrial fractions were used for biochemical assays. Total protein concentrations were determined using the method of Bradford (1976) with bovine serum albumin (SigmaAldrich Chemicals, France) as a standard. Hepatic biomarker assays including EROD, CYP3A, GST, were conducted, respectively, according to the methods of Flammarion et al. (1998), Miller et al. (2000) and Habig et al. (1974) adapted in microplate and optimized for gudgeon.

As with the liver, all muscle samples were homogenised, centrifuged to obtain the postmitochondrial fraction and total protein concentrations were determined. AChE activity was measured in muscle according the method developed by Ellman et al. (1961) adapted in a 96-well microplate.

Head kidneys were homogenised in potassium/phosphate buffer saline $\left(\mathrm{KH}_{2} \mathrm{PO}_{4} / \mathrm{K}_{2} \mathrm{HPO}_{4}, 0.1 \mathrm{M}, \mathrm{pH} 6.2\right.$; Sigma-Aldrich Chemicals, France). Homogenates were centrifuged at $3,450 \mathrm{~g}$ for $30 \mathrm{~min}$ at $4{ }^{\circ} \mathrm{C}$. The lysozyme activity was determined only in plasma samples of fish caught in 2008 , by the turbidimetric assay firstly described by Studnicka et al. (1986) and adapted in microplate. 


\subsection{Histological analysis}

After fixation of gonads in Bouin, three pieces of the gonad were dehydrated through a series of graded ethanol, cleared with toluene and embedded in paraffin. Sections were $7 \mu \mathrm{m}$ thick, stained with haematoxylin-eosin-saffron, and observed under optical microscope to determine fish gender and gonad abnormalities. To complete this analysis, three other sections of gonad were simultaneously stained with haematoxylinphloxin-light green in order to address the occurrence of yolk in oocytes.

\subsection{Fish assemblage analysis}

To assess disturbances of fish assemblage in the three investigated sites, sounding of all area with a depth below 1 meter was performed in August 2009, using portable electrofish material (Martin-Pêcheur, Dream Electronic). Fish species composition, specific richness and abundance were evaluated through several metrics such as number of total fish species, number of total fish for each species, fish length and total density of fish assemblage.

\subsection{Statistical analysis}

The CF, GSI and biomarker data are reported as mean \pm standard deviation. The SPSS 15.0 software was used for statistical analysis. Normal distribution and homoscedasticity of data were verified using Kolmogorov-Smirnov and Levene tests respectively $(\alpha=0.05)$. Since data sets did not have a normal distribution and/or homogeny of variance, the data was $\log$-transformed, using $\mathrm{F}(\mathrm{x})=\log (1+\mathrm{x})$, prior to parametric analysis. A two-way analysis of variance (ANOVA) was performed for each biomarker using sites and gender as factors to identify gender effect but no significant effect was recorded here. To determine the differences between biomarker responses measured in sampled sites, a one-way ANOVA followed by Sidak test $(\alpha=0.05)$ was 
performed. For VTG concentration, differences between sites were determined using a Kruskall-Wallis test followed by a Mann-Whitney test $(\alpha=0.05)$. Khi- 2 test. Sex-ratio differences between investigated sites were analyzed by Fisher's test $(\alpha=0.05)$.

\section{Results}

External examination of gudgeons revealed several features (Table 2). Abdominal pink colorations that could be due to tissue inflammation were observed at both upstream and downstream of investigated sites confirming the lack of absolute reference site in this study. Several haemorrhages were also observed in fish from sites A and B. During 2009 campaign, abdominal swelling was observed in three fish from both downstream locations. Internal examination of these gudgeons revealed hypertrophy of gonads (Figure 1) characterized by high gonado-somatic index (GSI) values between 21 and 51 $\%$. To compare, GSI measured in all other collected fish were between $8.9 \%$ for a maturing female and $0.4 \%$ for a male. In spite of these features, no significant difference of CF was recorded between sites (Table 2).

Results of biomarker responses are presented in table 3 and measured profiles are quite similar for both investigated years. Except for circulating VTG, no significant difference was recorded between upstream and downstream sampling sites for all investigated biomarkers. However, comparison with reference data (Table 3) indicated that EROD, CYP3A, GST and AChE activities are significantly modified in fish from

sites A, B and C. Vitellogenin concentrations measured in plasma of sampled gudgeons were presented in figure 2. Male fish from site B located downstream from the industrial effluent showed a significant induction of circulating VTG (747 to 1,660 $\mathrm{ng} / \mathrm{mL}$ and 3,521 to 4,983ng/mL for 2008 and 2009 respectively) as compared to fish 
from site A (86-682 ng/mL and 264-817 ng/mL for 2008 and 2009 respectively). For 2009, male gudgeons from site C were also characterized by high concentration of VTG $(1,759$ to $3,403 \mathrm{ng} / \mathrm{mL})$. Moreover, comparison of VTG concentrations measured in male female and intersex fish in 2009 showed that circulating concentrations in male and intersex gudgeons living in sites B and C were up to VTG concentrations in female from site A revealing the severity of this biochemical response.

Gonad histology revealed the presence of intersex gudgeons in all investigated sites in different proportions (Figures 3 and 4). Sites B and C were characterized by high level of histological disturbances respectively with $80 \%$ and $56 \%$ of intersex in 2008 and, 55 $\%$ and $44 \%$ of intersex in 2009. Fish from site A exhibited also intersex with a low level of occurrence (5\% and $8 \%$ for 2008 and 2009 respectively). Based on histological determination of fish gender in 2008 and 2009, sex ratio analysis was performed for gudgeon populations living in investigated sites (Figure 4). In upstream site (site A), $41 \%$ of gudgeons were males and $53 \%$ were females. Population from site B was characterized by an increase of intersex (63\%) associated to a decrease of males and females ratio (23\% and $13 \%$ respectively). In site $\mathrm{C}$, the ratio of male (38\%) was similar with the one measured in site A but a low ratio of female (4\%) was reported and associated to high occurrence of intersex (58\%). To complete this analysis of histological alterations and sex-ratio disturbances, haematoxylin-phloxin-light green staining was performed and confirmed the presence of yolk vesicules in secondary oocytes encountered in intersex gonads (data not shown) revealing an advanced stage of oocyte development due to normal development cycle of this cell in females and a strong impact of chemicals. The presence of advanced stage of oocyte development in intersex gonad indicates the severity of the intersexuality. Histological analysis of 
female and intersex gonads revealed that in sites $\mathrm{B}$ and $\mathrm{C}, 5 \%$ of fish were characterized by the presence of oocytes with two nucleus (Figure 3C).

Fish assemblage observed in site A was characterized by 8 significant fish species. A decrease was recorded in downstream sites with 6 and 3 fish species in sites B and C respectively (Table 4). More accurately, a decrease of sensitive fish species such as trout (Salmo trutta fario) and bullhead associated to presence of chub (Leuciscus cephalus), a resistant fish species was noticed in site B. Moreover, bullhead and gudgeon have almost disappeared in site $\mathrm{C}$ and an increase of stone loach (Barbatula barbatula), a fish species resistant to water quality degradation, was also observed. Degradation of fish assemblage between upstream and downstream sites was confirmed by a decrease of fish density (Table $4 ; 301,177$ and 74 fish $/ 938 \mathrm{~m}^{2}$ for sites A, B and C respectively).

\section{Discussion}

Numerous scientific studies address adverse effects induced by pollutants from effluents. Effects of wastewater treatment plant effluents are widely investigated particularly on reproductive function (Jobling et al., 1998, 2002a). Several studies assess also impact of effluents from paper industry (Larsson and Forlin, 2002), chemical industry (Olivares et al., 2010), mining activities (Kelly and Janz, 2009) or hospital (Escher et al., 2011). However, to our knowledge, no data is available on potential effects of pharmaceutical manufacture effluents on aquatic organisms living in collecting media. Hence, the aim of the present work was to assess individual and population effects downstream from discharge of pharmaceutical manufacture. 
Measurement of a set of exposure biomarkers including biotransformation enzymes, neurotoxicity and immunotoxicity biomarkers revealed no impact of investigated pharmaceutical effluent on selected end-points. Indeed, no significant difference was observed between upstream (site A) and downstream (sites B and C; Table 3). However, biomarker responses suggested fish exposure to various pollutants in the studied area. This hypothesis is supported i) by low level of EROD activity measured in gudgeons from various reference sites located in France and Switzerland (Flammarion et al., 1998; Faller et al., 2003) and ii) by biomarker responses of gudgeons from a reference site located in the Dore river upper area (Table 3) suggesting biotransformation enzyme inductions and $\mathrm{AChE}$ inhibition in sites A, B and C. Even if reference data collected in different hydromorphological contexts must be interpreted with caution (Sanchez et al., 2010), observed response profiles in sites A, B and C could reflect gudgeon exposure to organic compounds such as dioxin-like pollutants and/or pesticides. Detection of plasmatic VTG concentrations in male fish from site A (Figure 2) argues also for a contamination of upstream site by estrogenic compounds probably released in river by upstream urban WWTP. Indeed, this source of endocrine disruptor chemicals and associated estrogenic effects in fish are widely documented in several countries (Van Aerle et al., 2001; Jobling et al., 1998, 2002a). In France, a recent study reported adverse reproductive effects including male VTG induction and aromatase activity inhibition associated to an arrest of the gonadal development in wild male and female chubs (Leuciscus cephalus; Hinfray et al., 2010) living a small stream (i.e. the Jalle d'Eysines river) contaminated by steroidal estrogens (Labadie and Budzinski, 2005). In the present work, response profile of VTG was characterized by an induction in fish from downstream sites (sites B and C) and argued for an estrogenic effect in gudgeons 
exposed to both pharmaceutical manufacture and urban WWTP effluents. In the same locations, gudgeon population exhibited sex-ratio disturbances but the observed profile seems to be atypical (Figure 4). Indeed, numerous studies assessing endocrine disruption effects in fish living downstream effluents such as WWTP, reported VTG induction associated to feminization of fish (Van Aerle et al., 2001). In upstream site, intersex occurrence was up to $1 \%$ described as the basal incidence of intersexuality in a captive stock of gudgeons (Kestemont, 1987) indicating that fish from this site are probably exposed to feminizing chemicals. Moreover, our results revealed in downstream sites a strong increase of intersex fish associated to a decrease of females in both downstream sites suggesting masculinization of gudgeon population. In addition to intersex observation, $5 \%$ of female and intersex gudgeons from sites located downstream from pharmaceutical manufacture discharge were characterized by the presence of oocytes with more than one nucleus suggesting that chemicals have impaired cell division (Minier et al., 2000).

Results observed in the present work could be related to the presence of several APIs in the river. Indeed, by using a panel of in vitro assays applied to polar organic chemical integrative samplers (POCIS) deployed in the investigated area, Creusot et al. (in prep.) reported high activities linked to pregnage $\mathrm{X}$ receptor (PXR), androgen receptor (AR) but also progesterone, glucocorticoid and mineralocorticoid receptors (PR, GR and MR respectively) but no significant estrogenic activity in sites located downstream from the industrial effluent. Chemical analysis performed in POCIS extracts revealed high concentrations of dexamethasone, spironolactone and canrenone but also erythromycin and roxithromycin (Creusot et al., in prep.). Only few data reporting sex determination disturbances due to these chemicals is available. Howell et al. (1994) reported 
paradoxical masculinization of female western mosquitofish (Gambusia affinis) exposed to spironolactone. More recently, a study performed in pejerrey (Odontesthes bonariensis) showed complete masculinization of fish fed with dexamethasone or cortisol contaminated diets and confirms that GR agonists can disrupt sex differenciation in fish (Hattori et al., 2009). Few data related to the effects of synthetic gestagens on reproductive function of fish is also available but adult fathead minnow (Pimephales promelas) exposure to progestins such as norethindrone, levonorgestrel and drospirenone at concentrations between 1 and $100 \mathrm{ng} / \mathrm{L}$ resulted in masculinization of females with de novo synthesis of nuptial tubercles (Zeilinger et al 2009; Paulos et al., 2010). Overall, this previous data together with our observations on sex ratio alteration supports the hypothesis of a gudgeon population masculinization due to APIs exposure downstream of industrial effluent addressed in the present work. However, further studies are needed to assess accurately the mechanism of action of these chemical compounds, alone and in mixture, on fish reproductive function and to evaluation their involvement in the present observations.

In this study, biochemical and histological changes were associated to fish population disturbance characterized by a decrease of fish density and a lack of sensitive fish species in downstream sites (Table 3). Few studies reported a relationship between individual and population effects and to our knowledge, only estrogenic effects are investigated in this context. Recent studies demonstrate, in roach (Rutilus rutilus), an adverse effect of male intersex on reproductive performance characterized by a decrease of spermatozoid number and a decrease of fertilization rate associated to an effect on parentage outcome in the investigated population (Jobling et al., 2002b; Harris et al., 2011) and support the observation of Kidd et al. (2007) reporting a collapse of fish 
population in a lake experimentally contaminated by synthetic estrogen ethynylestradiol. These results support the hypothesis that intersexuality is critical for the reproductive success of fish. No similar data is available in fish population exhibiting masculinization phenomenon. Population viability analysis performed in male-biased eelpout (Zoarces viviparus) population living downstream pulp mill effluents (Larsson and Forlin, 2002), using a female-based matrix population model reported a risk of total pseudo extinction for the 20 and 50-year time horizons in populations with respectively $4 \%$ and $13 \%$ female fry (Hanson et al., 2005). This data cannot be strictly transposed to gudgeon populations investigated here but indicates that resident fish populations could disappear due to sex ratio disturbances and fish persistence could be linked to downstream migration.

\section{Conclusions}

This study was designed to assess individual and population effects induced by mixture of urban WWTP and pharmaceutical manufacture discharges in wild fish. For this purpose, a set of biochemical and histological biomarkers was measured in gudgeons from upstream and downstream sites and fish assemblage was characterized. Results presented in this paper show that fish living downstream from pharmaceutical manufacture discharge exhibited severe signs of endocrine disruption as shown by high level of circulating VTG concentrations, high proportion of intersex fish and a malebiased sex-ratio. These effects were associated to fish population disturbances with a decrease of occurrence of sensitive fish species and fish density. No cause-effect relationship can be firmly established between fish exposure to APIs, individual and population disturbances, but a set of evidence supports the hypothesis that these 
compounds induce observed adverse effects and indicates that resident fish populations from both downstream sites could disappear. Results of this field study argue for:

i) the increase of knowledge related to mechanisms of action of single APIs and associated effects in fish and other aquatic organisms. Indeed, few data is available to explain the adverse effects reported in the present work and probably due to chemical with activities linked to other receptors than well-known ER such as PXR, AR, PR, GR. Moreover, pharmaceutical factory effluents are a mixture of APIs with various mechanisms of action. Also, it appears as relevant to increase knowledge related to the effects of API mixtures. For this purpose, laboratory experiments can be performed using characterized mixtures but studies based on effluent derivation could be performed to address effects of environmental relevant mixture in wild fish; ii) the deployment of specific monitoring of pharmaceutical factory discharges, capable of assessing health of fish and aquatic communities. In this context, effect-based monitoring tools such as biochemical and histological biomarkers appear as a valuable methodology. The present work shows also that effluents can be discharged in polluted environment and effects measured at downstream sites cannot be ascribed to a specific effluent but to a mixture of pollutant sources. Also, the deployment of an effect-directed analysis could be considered as a valuable approach to identify sources involved in the observed adverse effects.

iii) policy decisions related to environmental protection and fishery resource conservation. Indeed, a recent modelisation study performed on wild intersex roach populations suggested that combination between intersexuality and selective fishing practice increases the extinction risk of fish species in local population (An et al., 2009). 


\section{Acknowledgements}

This work was supported by the French Ministry of Ecology and Sustainable

Development (Programme 181 - DRC43). We thank the technical staff from the "Office

National de l'Eau et des Milieux Aquatiques" for the assistance in fish sampling. We thank also Pr. Patrick Kestemont from FUNDP, Namur for recommendations for histological analysis of gonads.

Ethical considerations: Procedures described in the present paper were conducted in accordance with laws and regulations controlling animal experiments in France. All experimental protocols were approved by the Ethical Committee of the French National Institute of Industrial Environment and Risks.

\section{References}

An W, Hu J, Giesy JP, Yang M. Extinction risk of exploited wild roach (Rutilus rutilus) populations due to chemical feminization. Environ Sci Technol 2009; 43: 7895-7901. Blazer VS. Histopathological assessment of gonadal tissue in wild fishes. Fish Physiol Biochem 2002; 26: 85-101.

Bradford MM. A rapid sensitive method for the quantitation of microgram quantities of protein utilizing the principle of protein-dye binding. Anal Biochem 1976; 72: 248-254. Brion F, Rogerieux F, Noury P, Migeon B, Flammarion P, Thybaud E, Porcher JM. Two step purification method of vitellogenin from three teleost fish species: rainbow trout (Oncorhynchus mychiss), gudgeon (Gobio gobio) and chub (Leuciscus cephalus). J Chrom B 2000; 737: 3-12. 
Brown KD, Kulis J, Thomson B, Chapman TH, Mawhinney DB. Occurrence of antibiotics in hospital, residential, and dairy effluent, municipal wastewater, and the Rio Grande in New Mexico. Sci Total Environ 2006; 366: 772-783.

Ellman GL, Courtney KD, Andres Jr V, Featherstone RM. A new and rapid colorimetric determination of acetylcholinesterase activity. Biochem Pharmacol 1961; 7: 88-95.

Escher BI, Baumgartner R, Koller M, Treyer K, Lienert J, McArdell CS. Environmental toxicology and risk assessment of pharmaceuticals from hospital wastewater. Water Res 2011; 45: 75-92.

Faller P, Kobler B, Peter A, Sumpter J.P, Burkhardt-Holm P. Stress status of gudgeon (Gobio gobio) from rivers in switzerland with and without input of sewage treatment plant effluent. Environ Toxicol Chem 2003; 22: 2063-2072.

Fent K, Weston AA, Caminada D. Ecotoxicology of human pharmaceuticals. Aquatic Toxicol 2006; 76: 122-159.

Flammarion P, Migeon B, Garric J. Statistical Analysis of Cyprinid Ethoxyresorufin-Odeethylase Data in a Large French Watershed. Ecotoxicol Environ Saf 1998; 40: 144153.

Gagne F, Blaise, C. Effects of pharmaceuticals on aquatic biota - a review. Curr Top Toxicol 2004; 1: 73-86.

Habig WH, Pabst MJ, Jakoby WB. Glutathione S-Transferases. The first enzymatic step in mercapturic acid formation. J Biol Chem 1974; 249: 7130-7139.

Halling-Sørensen B, Nors Nielsen S, Lanzky PF, Ingerslev F, Holten Lützhøft HC, Jørgensen SE. Occurrence, fate and effects of pharmaceutical substances in the environment- A review. Chemosphere 1998; 36: 357-393. 
Hanson N, Aberg P, Sundelof A. Population-level effects of male-biased broods in eelpout (Zoarces viviparus). Environ Toxicol Chem 2005; 24: 1235-1241.

Harris CA, Hamilton PB, Runnalls TJ, Vinciotti V, Henshaw A, Hodgson D, Coe TS, Jobling S, Tyler CR, Sumpter JP. The consequences of feminization in breeding groups of male fish. Environ Health Perspect 2011; 119: 306-311.

Hattori RS, Fernandino JI, Kishii A, Kimura H, Kinno T, Oura M, Somoza GM, Yokota M, Strüssmann CA, Watanabe S. Cortisol-Induced Masculinization: Does Thermal Stress Affect Gonadal Fate in Pejerrey, a Teleost Fish with Temperature-Dependent Sex Determination? PLOS one 2009; 4: e6548. doi: 10.1371/journal.pone.0006548

Heincke F. Bericht über die Untersuchungen der Biologischen Anstalt auf Helgoland zur Naturgeschichte der Nutzfische. Die Beteiligung Deutschlands an der Internationalen Meeresforschung 1908; 4/5: 67-155.

Hinfray N, Palluel O, Piccini B, Sanchez W, Aït-Aïssa S, Noury P, Gomez E, Geraudie P, Minier C, Brion F, Porcher JM. Endocrine disruption in wild populations of chub (Leuciscus cephalus) in contaminated French streams. Sci Total Environ 2010; 408: 2146-2154.

Howell WL, Hunsinger RN, Blanchard PD. Paradoxical masculinization of female Western Mosquitofish during exposure to spironolactone. Prog Fish Culturist 1994; 56: $51-55$.

Huet M. Aperçu des relations entre la pente et les populations piscicoles des eaux courantes. Schweizerische Zeitschrift für Hydrologie 1949; I1: 332-351.

Jobling S, Nolan M, Tyler CR, Brighty G, Sumpter JP. Widespread Sexual Disruption in Wild Fish. Environ Sci Technol 1998; 32: 2498-2506. 
Jobling S, Beresford N, Nolan M, Rodgers-Gray T, Brighty GC, Sumpter JP, Tyler CR. Altered Sexual Maturation and Gamete Production in Wild Roach (Rutilus rutilus) Living in Rivers That Receive Treated Sewage Effluents. Biol Reprod 2002a; 66: 272281.

Jobling S, Coey S, Whitmore JG, Kime DE, Van Look KJW, McAllister BG, Beresford N, Henshaw AC, Brighty G, Tyler CR, Sumpter JP. Wild intersex roach (Rutilus rutilus) have reduced fertility. Biol Reprod 2002b; 67: 515-524.

Kelly JM, Janz DM. Assessment of oxidative stress and histopathology in juvenile northern pike (Esox lucius) inhabiting lakes downstream of a uranium mill. Aquat Toxicol 2009; 92: 240-249.

Kestemont P. Etude du cycle reproducteur du goujon, Gobio gobio L. 1. Variations saisonnières dans l'histologie de l'ovaire. J Appl Ichthyol 1987; 3: 145-157.

Kidd K.A, Blanchfield PJ, Mills KH, Palace VP, Evans RE, Lazorchak JM, Flick RW. Collapse of a fish population after exposure to a synthetic estrogen. P Natl Aca Sci USA 2007; 104: 8897-8901.

Kümmerer K. Drugs in the environment: emission of drugs, diagnostic aids and disinfectants into wastewater by hospitals in relation to other sources - a review. Chemosphere 2001; 45: 957-969.

Kümmerer K. The presence of pharmaceuticals in the environment due to human use present knowledge and future challenges. J Environ Manage 2009; 90: 2354-2366

Labadie P, Budzinski H. Determination of steroidal hormone profiles along the Jalle d'Eysines river (near Bordeaux, France). Environ Sci Technol 2005; 39: 5113-5120. 
Larsson DGJ, Förlin L. Male-biased sex ratios of fish embryos near a pulp mill: temporary recovery after a short-term shutdown. Environ Health Persp 2002; 110: 739742.

Larsson DGJ, de Pedro C, Paxeus N. Effluent from drug manufactures contains extremely high levels of pharmaceuticals. J Hazard Mater 2007; 148: 751-755.

Matamoros V, Arias C, Brix H, Bayona JM. Preliminary screening of small-scale domestic wastewater treatment systems for removal of pharmaceutical and personal care products. Water Res 2009; 43: 55-62.

Laville N, Aït-Aïssa S, Gomez E, Casellas C, Porcher JM. Effects of human pharmaceuticals on cytotoxicity, EROD activity and ROS production in fish hepatocytes. Toxicology 2004; 196: 41-55.

Miller VP, Stresser DM, Blanchard AP, Turner S, Crespi CL. Fluorimetric highthroughput screening for inhibitors of cytochrome P450. Ann NY Aca Sci 2000; 919: 26-32.

Minier C, Caltot G, Leboulanger F, Hill EM. An investigation of the incidence of intersex fish in Seine-Maritime and Sussex regions. Analusis 2000; 28: 801-806.

Mimeault C, Woodhouse AJ, Miao XS, Metcalfe CD, Moon TW, Trudeau VL. The human lipid regulator, gemfibrozil bioconcentrates and reduces testosterone in the goldfish, Carassius auratus. Aquat Toxicol 2005; 73: 44-54.

Nash JP, Kime DE, Van der Ven LTM, Wester PW, Brion F, Maack G, StahlschmidtAllner P, Tyler CR. Long-term exposure to environmental concentrations of the pharmaceutical ethynylestradiol causes reproductive failure in fish. Environ Health Persp 2004; 112: 1725-1733. 
Olivares A, Quirós L, Pelayo S, Navarro A, Bosch C, Grimalt JO, Fabregat MdC, Faria M, Benejam L, Benito J, Solé M, Barata C, Piña B. Integrated biological and chemical analysis of organochlorine compound pollution and of its biological effects in a riverine system downstream the discharge point. Sci Total Environ 2010; 408: 5592-5599.

Pagano G, de Biase A, Deeva IB, Degan P, Doronin YK, Iaccarino M, Oral R, Trieff NM, Warnau M, Korkina LG. The role of oxidative stress in developmental and reproductive toxicity of tamoxifen. Life Sci 2001; 68: 1735-1749.

Paulos P, Runnalls TJ, Nallani G, La Point T, Scott AP, Sumpter JP, Huggett DB. Reproductive responses in fathead minnow and Japanese medaka following exposure to a synthetic progestin, Norethindrone. Aquat Toxicol 2010; 99: 256-262.

Phillips PJ, Smith SG, Kolpin DW, Zaugg SD, Buxton HT, Furlong ET, Esposito K, Stinson B. Pharmaceutical formulation facilities as sources of opioids and other pharmaceuticals to wastewater treatment plant effluents. Environ Sci Technol 2010; 44: 4910-4916.

Rabiet M, Togola A, Brissaud F, Seidel JL, Budzinski H, Elbaz-Poulichet F. Consequences of Treated Water Recycling as Regards Pharmaceuticals and Drugs in Surface and Ground Waters of a Medium-sized Mediterranean Catchment. Environ Sci Technol 2006; 40: 5282-5288.

Sanchez W, Porcher JM. Fish biomarkers for environmental monitoring within the Water framework Directive of the European Union. TRAC-Trend Anal Chem 2009; 28: $150-158$.

Sanchez W, Piccini B, Maillot-Maréchal E, Porcher JM. Comparison of two reference systems for biomarker data analysis in a freshwater biomonitoring context. Environ Int 2010; 36: 377-382. 
Santos JL, Aparicio I, Callejón M, Alonso E. Occurrence of pharmaceutically active compounds during 1-year period in wastewaters from four wastewater treatment plants in Seville (Spain). J Hazard Mater 2009; 164: 1509-1516.

Sim WJ, Lee JW, Lee ES, Shin SK, Hwang SR, Oh JE. Occurrence and distribution of pharmaceuticals in wastewater from households, livestock farms, hospitals and pharmaceutical manufactures. Chemosphere 2011; 82: 179-186.

Studnicka M, Siwicki A, Ryka B. Lysozyme level in carp (Cyprinus carpio L.). Bamidgeh 1986; 1: 22 -25.

Tamtam F, Mercier F, Le Bot B, Eurin J, Tuc Dinh Q, Clément M, Chevreuil M. Occurrence and fate of antibiotics in the Seine River in various hydrological conditions. Sci Total Environ 2008; 393: 84-95.

Thibaut R, Schnell S, Porte C. The tnterference of pharmaceuticals with endogenous and xenobiotic metabolizing enzymes in carp liver: an in-vitro study. Environ Sci Technol 2006; 40: 5154-5160.

Togola A, Budzinski H. Multi-residue analysis of pharmaceutical compounds in aqueous samples. J Chrom A 2008; 1177: 150-158.

van Aerle R, Nolan M, Jobling S, Christiansen LB, Sumpter JP, Tyler CR. Sexual disruption in a second species of wild cyprinid fish (the gudgeon, Gobio gobio) in United Kingdom freshwaters. Environ Toxicol Chem 2001; 20: 2841-2847.

Yu-Chen Lin A, Tsai YT. Occurrence of pharmaceuticals in Taiwan's surface waters: Impact of waste streams from hospitals and pharmaceutical production facilities. Sci Total Environ 2009; 407: 3793-3802.

Zeilinger J, Steger-Hartmann T, Maser E, Goller S, Vonk R, Lange R. Effects of synthetic gestagens on fish reproduction. Environ Toxicol Chem 2009; 28: 2663-2670. 
Figure captions

Figure 1. Abdominal swelling (A) observed in gudgeons (Gobio gobio) from site C located downstream from an urban waste water treatment plant and pharmaceutical manufacture effluent and associated gonad hypertrophy (B). Total length of presented fish is $179.4 \mathrm{~mm}$.

Figure 2. Concentration of circulating VTG in male (M), intersex (I) and female (F) gudgeons (Gobio gobio) from the three investigated Dore' sites in 2008 (A) and 2009 (B). Male and intersex data were pooled for statistical analysis. Different letters indicate statistically significant differences $(\mathrm{p}<0.05$; Kruskall-Wallis test followed by MannWhitney post-hoc test).

Figure 3. Histological analysis of gudgeon (Gobio gobio) gonads after haematoxylineosin-saffron staining. A: Gonad of female from site A located downstream from an urban WWTP and upstream from pharmaceutical factory discharge, B: Gonad of male from site A, C: Intersex gonad with primary oocytes observed in fish from site B located downstream from an urban WWTP and pharmaceutical factory discharge, D: Intersex gonad with primary and secondary oocytes observed in fish from site $\mathrm{B}$. $\mathrm{PO}=$ primary oocyte, $\mathrm{SO}=$ secondary oocyte, $\mathrm{Sg}=$ spermatogonia, $\mathrm{Sc}=$ spermatocyte, $\mathrm{N}=$ oocyte with 2 nucleus. 
Figure 4. Analysis of sex-ratio in gudgeon (Gobio gobio) populations from the three investigated sites. ${ }^{*}$ depicts a statistically significant difference as compared to the site $A(p<0.05 ;$ Fisher's test $)$. 
Table 1. Sampled site location and identified environmental pressure

\begin{tabular}{|c|c|c|c|c|}
\hline River & Site & GPS coordinates & $\begin{array}{l}\text { Length to } \\
\text { spring }(\mathrm{km})\end{array}$ & Pressure \\
\hline \multirow[t]{3}{*}{ Dore } & A & $\begin{array}{l}45^{\circ} 35^{\prime} 46^{\prime \prime} \mathrm{N} \\
3^{\circ} 43^{\prime} 21^{\prime \prime} \mathrm{E}\end{array}$ & 61,5 & $\begin{array}{l}\text { Site located downstream from } \\
\text { an urban WWTP of medium } \\
\text { size city }\end{array}$ \\
\hline & B & $\begin{array}{l}45^{\circ} 38^{\prime} 56^{\prime}, \mathrm{N} \\
3^{\circ} 40^{\prime} 31^{\prime \prime} \mathrm{E}\end{array}$ & 70,8 & $\begin{array}{l}\text { Site located downstream from } \\
\text { urban and industrial discharges }\end{array}$ \\
\hline & $\mathrm{C}$ & $\begin{array}{l}45^{\circ} 41^{\prime} 58^{\prime \prime} \mathrm{N} \\
3^{\circ} 374511^{\prime \prime} \mathrm{E}\end{array}$ & 81 & $\begin{array}{l}\text { Dilution of pressure from site } \\
\text { B }\end{array}$ \\
\hline
\end{tabular}


Table 2. Fish number, external examination and condition factor for gudgeons (Gobio gobio) caught at the Dore river. For both investigated year, data is presented separately (2008/2009). Condition factor is reported as mean \pm standard deviation and values not sharing a common letter within parameter are statistically different from each other $(\mathrm{p}<0.05)$. 


\begin{tabular}{|c|c|c|c|c|}
\hline & Year & Site A & Site B & Site C \\
\hline \multirow[t]{2}{*}{ Fish number (M/I/F) } & 2008 & $12(4 / 1 / 7)$ & $10(1 / 8 / 1)$ & $12(4 / 7 / 1)$ \\
\hline & 2009 & $20(9 / 1 / 10)$ & $20(6 / 11 / 3)$ & $18(10 / 8 / 0)$ \\
\hline \multirow[t]{2}{*}{ Fish length (mm) } & 2008 & $124.5 \pm 22.5^{\mathrm{a}}$ & $133.6 \pm 18.8^{\mathrm{a}}$ & $124.2 \pm 10.9^{\mathrm{a}}$ \\
\hline & 2009 & $138.4 \pm 10.4^{\mathrm{a}}$ & $147.2 \pm 6.8^{\mathrm{ab}}$ & $152.5 \pm 15.2^{b}$ \\
\hline \multirow[t]{2}{*}{ Fish weight (g) } & 2008 & $22.0 \pm 12.0^{\mathrm{a}}$ & $26.5 \pm 10.4^{\mathrm{a}}$ & $19.2 \pm 4.4^{\mathrm{a}}$ \\
\hline & 2009 & $27.1 \pm 8.0^{\mathrm{a}}$ & $35.1 \pm 8.4^{\mathrm{ab}}$ & $37.3 \pm 8.9^{b}$ \\
\hline \multirow[t]{2}{*}{ Male GSI (\%) } & 2008 & $1.11 \pm 0.36^{\mathrm{a}}$ & 0.65 & $0.79 \pm 0.39^{b}$ \\
\hline & 2009 & $0.65 \pm 0.18^{a}$ & $0.67 \pm 0.22^{\mathrm{a}}$ & $0.84 \pm 0.34^{\mathrm{a}}$ \\
\hline \multirow[t]{2}{*}{ Intersex GSI (\%) } & 2008 & 1.40 & $1.25 \pm 1.11^{\mathrm{a}}$ & $2.57 \pm 1.99^{\mathrm{a}}$ \\
\hline & 2009 & 3.30 & $0.77 \pm 0.30^{\mathrm{a}}$ & $10.98 \pm 17.66^{\mathrm{a}}$ \\
\hline \multirow[t]{2}{*}{ Female GSI (\%) } & 2008 & $4.15 \pm 1.32$ & 2.14 & 4.68 \\
\hline & 2009 & $1.76 \pm 0.79^{\mathrm{a}}$ & $1.24 \pm 0.50^{\mathrm{a}}$ & - \\
\hline \multirow[t]{2}{*}{ Condition factor } & 2008 & $1.05 \pm 0.18^{\mathrm{a}}$ & $1.08 \pm 0.16^{\mathrm{a}}$ & $1.00 \pm 0.16^{\mathrm{a}}$ \\
\hline & 2009 & $1.00 \pm 0.14^{\mathrm{a}}$ & $1.09 \pm 0.18^{\mathrm{a}}$ & $1.06 \pm 0.21^{\mathrm{a}}$ \\
\hline Abdominal & 2008 & 1 & 4 & 3 \\
\hline coloration (n) & 2009 & 9 & 12 & 8 \\
\hline \multirow[t]{2}{*}{ Hemorrhage (n) } & 2008 & 1 & 3 & 0 \\
\hline & 2009 & 0 & 0 & 0 \\
\hline Abdominal swelling & 2008 & 0 & 0 & 0 \\
\hline (n) & 2009 & $\begin{array}{r}0 \\
28\end{array}$ & 1 & 2 \\
\hline
\end{tabular}


M/I/F = Male/Intersex $/$ Female

$\mathrm{n}=$ number of fish 
Table 3. Biomarker responses for gudgeons (Gobio gobio) caught at the Dore river. Data is reported as mean \pm standard deviation except for vitellogenin that is reported as geometrical mean \pm confident interval. Values not sharing a common letter within biomarker are statistically different from each other $(\mathrm{p}<0.05)$. nd: not determined. 


\begin{tabular}{|c|c|c|c|c|c|}
\hline & Year & Reference & Site A & Site B & Site C \\
\hline EROD & 2008 & nd & $41.0 \pm 35.2^{\mathrm{a}}$ & $41.1 \pm 38.0^{\mathrm{a}}$ & $53.7 \pm 48.7^{\mathrm{a}}$ \\
\hline$(\mathrm{pmol} / \mathrm{min} / \mathrm{mg})$ & 2009 & $12.8 \pm 7.4^{\mathrm{a}}$ & $32.5 \pm 18.6^{b}$ & $29.6 \pm 19.3^{b}$ & $36.9 \pm 17.0^{b}$ \\
\hline CYP3A & 2008 & nd & $2.9 \pm 1.5^{\mathrm{a}}$ & $2.1 \pm 1.7^{\mathrm{a}}$ & $2.6 \pm 2.1^{\mathrm{a}}$ \\
\hline (pmol/h/mg) & 2009 & $1.7 \pm 0.4^{\mathrm{a}}$ & $2.4 \pm 1.8^{\mathrm{ab}}$ & $3.6 \pm 2.2^{\mathrm{a}}$ & $3.0 \pm 1.7^{\mathrm{a}}$ \\
\hline GST & 2008 & nd & $4114 \pm 927^{\mathrm{a}}$ & $3865 \pm 645^{\mathrm{a}}$ & $4568 \pm 689^{a}$ \\
\hline$(\mathrm{U} / \mathrm{g})$ & 2009 & $1587 \pm 426^{\mathrm{a}}$ & $3836 \pm 755^{b}$ & $4627 \pm 937^{b}$ & $4106 \pm 716^{b}$ \\
\hline $\mathrm{AChE}$ & 2008 & nd & $137 \pm 20^{\mathrm{a}}$ & $141 \pm 36^{\mathrm{a}}$ & $143 \pm 21^{\mathrm{a}}$ \\
\hline (U/mg prot.) & 2009 & $184 \pm 45^{\mathrm{a}}$ & $118 \pm 16^{b}$ & $134 \pm 22^{b}$ & $151 \pm 24^{b}$ \\
\hline Lysozyme & 2008 & nd & $294 \pm 204^{\mathrm{a}}$ & $330 \pm 175^{a}$ & $282 \pm 132^{\mathrm{a}}$ \\
\hline (U/g kidney) & 2009 & nd & nd & nd & nd \\
\hline
\end{tabular}


Table 4. Number of significant fish species electrofished in 2009 on the three Dore river investigated sites and associated fish density (number of fish/938m²).

\begin{tabular}{lccc}
\hline & Site A & Site B & Site C \\
\hline Salmo trutta fario & 13 & 9 & 9 \\
Salmo salar & 30 & 16 & - \\
Cottus gobio & 59 & 42 & - \\
Phoxinus phoxinus & 70 & 18 & - \\
Gobio gobio & 64 & 40 & 28 \\
Barbatula barbatula & 12 & - & 2 \\
Alburnoides bipunctatus & 34 & - & - \\
Barbus barbus & 8 & 41 & - \\
\hline Leuciscus cephalus & & & \\
\hline Density & 301 & & \\
\hline
\end{tabular}




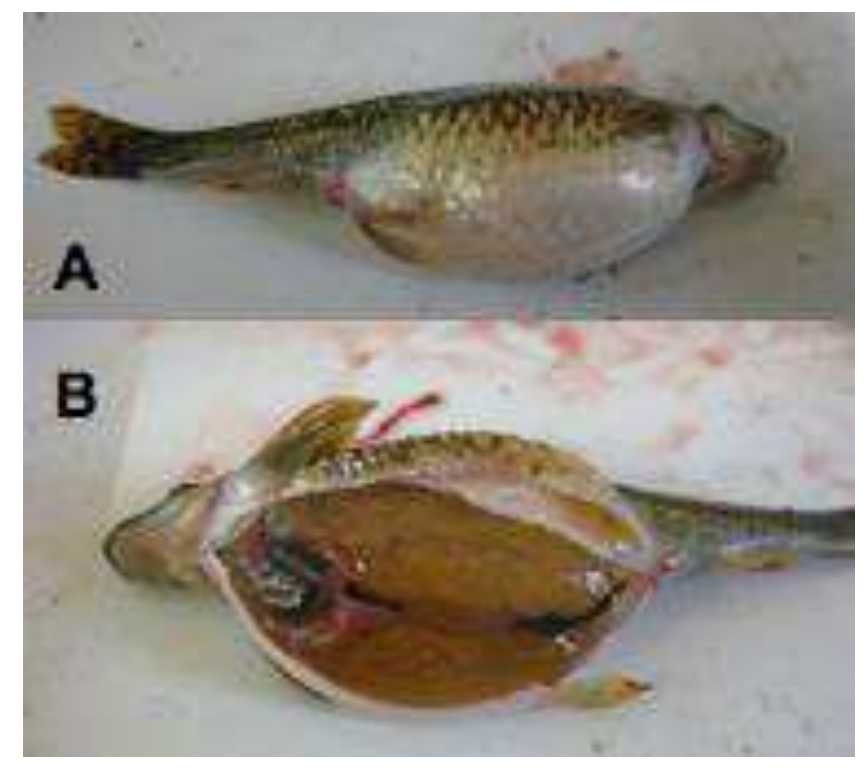

Figure 1. Abdominal swelling (A) observed in gudgeons (Gobio gobio) from site C located downstream from an urban waste water treatment plant and pharmaceutical manufacture effluent and associated gonad hypertrophy (B). Total length of presented fish is $179.4 \mathrm{~mm}$. 

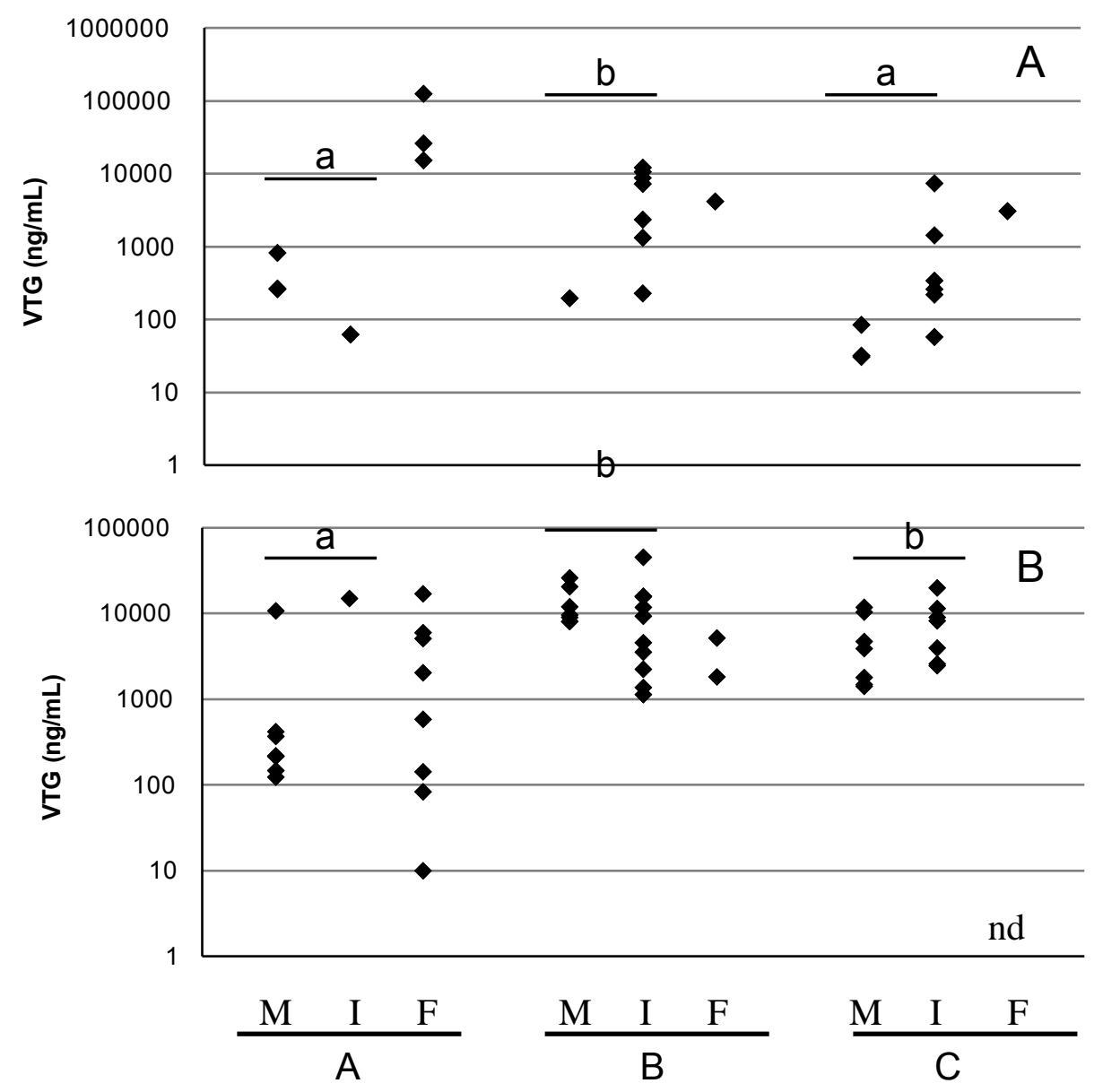

Figure 2. Concentration of circulating VTG in male (M), intersex (I) and female (F) gudgeons (Gobio gobio) from the three investigated Dore' sites in 2008 (A) and 2009 (B). Male and intersex data were pooled for statistical analysis. Different letters indicate statistically significant differences $(\mathrm{p}<0.05$; Kruskall-Wallis test followed by Mann-Whitney post-hoc test). 

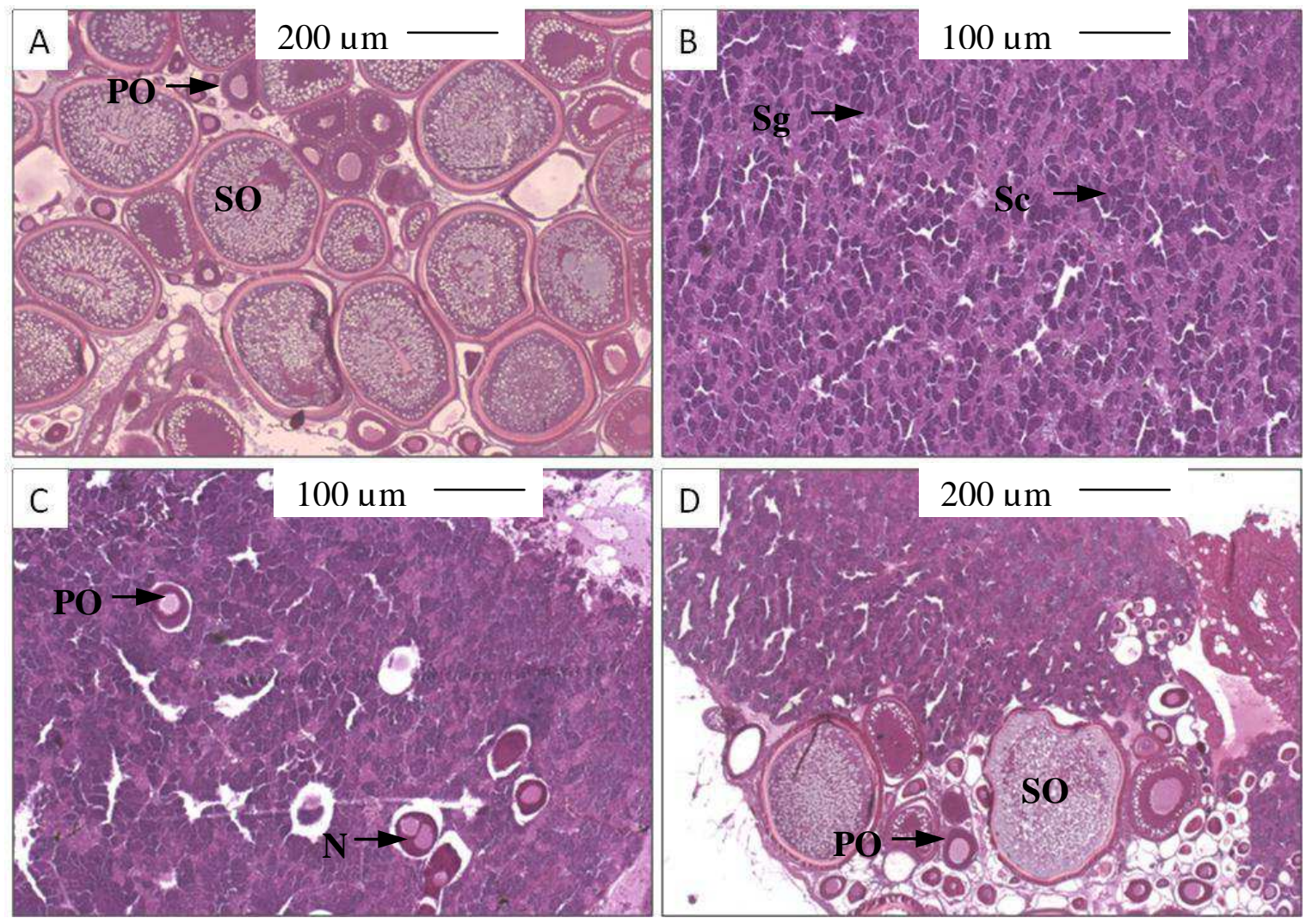

Figure 3. Histological analysis of gudgeon (Gobio gobio) gonads after haematoxylin-eosinsaffron staining. A: Gonad of female from site A located downstream from an urban WWTP and upstream from pharmaceutical factory discharge, B: Gonad of male from site A, C: Intersex gonad with primary oocytes observed in fish from site B located downstream from an urban WWTP and pharmaceutical factory discharge, D: Intersex gonad with primary and secondary oocytes observed in fish from site $\mathrm{B} . \mathrm{PO}=$ primary oocyte, $\mathrm{SO}=$ secondary oocyte, $\mathrm{Sg}=$ spermatogonia, $\mathrm{Sc}=$ spermatocyte, $\mathrm{N}=$ oocyte with 2 nucleus. 


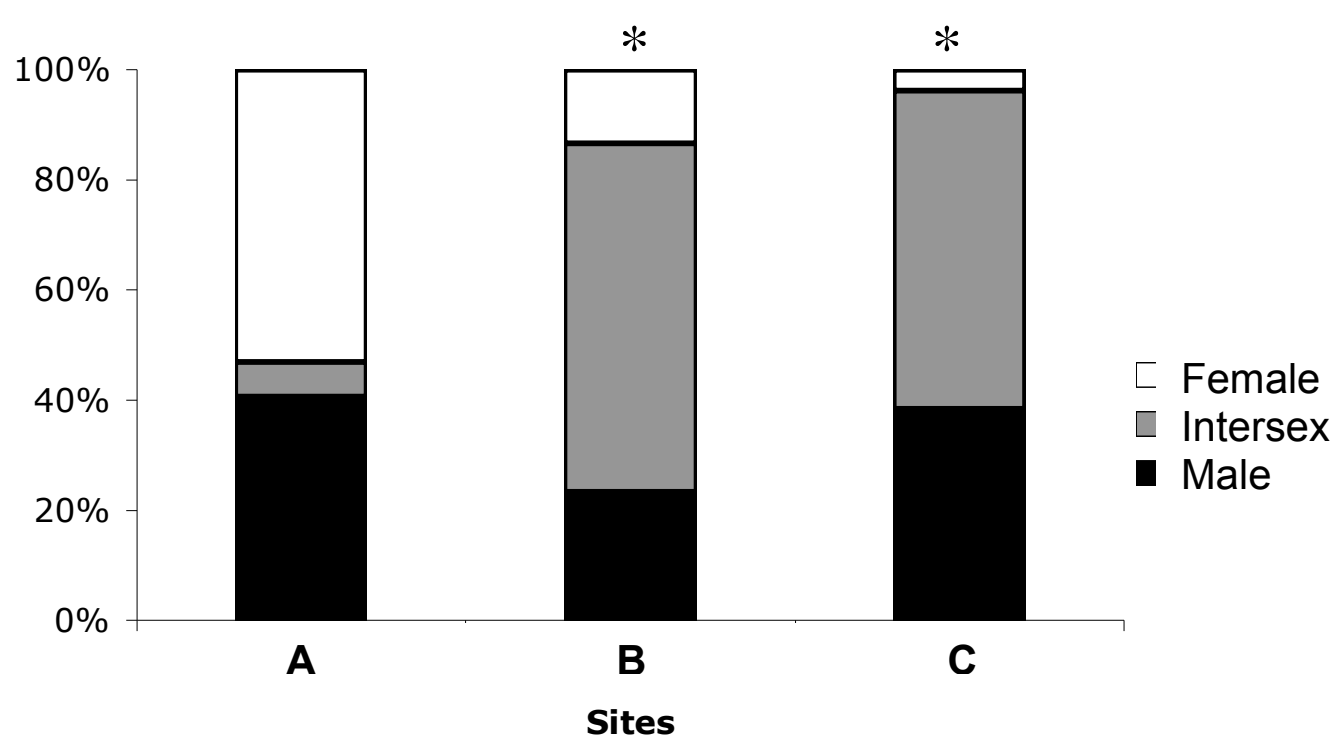

Figure 4. Analysis of sex-ratio in gudgeon (Gobio gobio) populations from the three investigated sites. * depicts a statistically significant difference as compared to the site A $(\mathrm{p}<0.05 ;$ Fisher's test). 